DOI: 10.34220/DSPPD2021_29-34

УДК. 159.9.07

Моисеева Мария Петровна, магистрант 1 курса, Воронежский государственный педагогический университет

\author{
ИССЛЕДОВАНИЕ ПСИХОЛОГИЧЕСКОГО БЛАГОПОЛУЧИЯ \\ СТУДЕНТОВ-ПСИХОЛОГОВ В УСЛОВИЯХ ДИСТАНЦИОННОГО \\ ОБУЧЕНИЯ
}

\title{
STUDY OF PSYCHOLOGICAL WELL-BEING OF PSYCHOLOGIST STUDENTS IN THE CONDITIONS OF DISTANCE LEARNING
}

Аннотация: В статье дана краткая характеристика структуры психологического благополучия личности. Рассмотрены основные концепции психологического благополучия личности. Описаны компоненты психологического благополучия в исследовании и описаны результаты исследования психологического благополучия студентов-психологов в условиях дистанционного обучения.

Abstract: The article provides a brief description of the structure of the psychological wellbeing of the individual. The basic concepts of psychological well-being of the individual are considered. The components of psychological well-being in the study are described and the results of the study of the psychological well-being of psychology students in the conditions of distance learning are described.

Ключевые слова: Психологи, студенты, студенты-психологи, субъективное благополучие, психологическое благополучие, дистанционное обучение

Keywords: Psychologists, students, psychology students, subjective well-being, psychological well-being, distance learning

В связи со сложившейся эпидемиологической обстановкой в мире, многие студенты перешли на дистанционную форму обучения. Она имеет свои специфические особенности, кардинально отличающиеся от аудиторной формы работы. Процесс удаленного преподавания является более трудоемким, поскольку для этого требуется крайне детальная организация учебных курсов. Наряду с этим, студенты обладают разными возможностями присоединения к видеоконференциям.

\footnotetext{
${ }^{\circ}$ Моисеева М.П., 2021
} 
Необходимо отметить, что главным фактором, влияющим на успешность обучения студента, является состояние психологического комфорта. Резкое изменение условий обучения может сказаться, в первую очередь, на его благополучии, самочувствии, самооценке, удовлетворенности жизнью, самосознании, которые, в свою очередь, имеют большое значение в психологическом здоровье. Негативное влияние дистанционного обучения на психологическое благополучие обучающегося может привести к ухудшению успеваемости по дисциплинам и снижению учебной мотивации. Данная проблема и определила цель нашего исследования: изучить психологическое благополучие студентов-психологов в период дистанционного обучения.

В конце 60-х годов XX века Н. Брэдберн [8, С. 122] ввел понятие «психологическое благополучие». В своей работе автор говорит о том, что модель психологического благополучия представляет собой баланс между положительным и негативными аффектами.

Рассмотрим модель психологического благополучия М. Ягоды. Обобщив исследования, М. Ягода привел модель к следующему вид: самопринятие (высокая самооценка), личностный рост, интегрированность, автономность, точность восприятия реальности, компетентность в отношении окружающей социальной среды [1, С. 32].

К. Рифф опираясь на данные Н. Брэдберна и М. Ягоды определила собственную модель психологического благополучия и создала опросник «Шкала психологического благополучия». Согласно К. Рифф [7, С. 69] психологическое благополучие - базовый субъективный конструкт, который отражает восприятие и оценку своего функционирования.

Нами было проведено исследование уровня психологического благополучия студентов-психологов, которые обучаются на втором и третьем курсе по направлению «Психология личности».

Объект исследования: психологическое благополучие личности.

Предмет исследования: психологическое благополучие студентовпсихологов в условиях дистанционного обучения.

Гипотезой нашего исследования выступило предположение о том, что студенты-психологи в условиях дистанционного обучения обладают средними или высокими показателями психологического благополучия: сниженным 
уровнем тревоги, средним уровнем толерантности к неопределенности, и средними результатами по шкале психологического благополучия.

Исследование проводилось на базе Воронежского Государственного Университета. В нем принимали участие студенты-психологи 2 и 3 курсов направления «Психология личности» в количестве 15 человек.

Психодиагностическим инструментарием выступили следующие методики:

1. «Шкала психологического благополучия» К. Рифф в адаптации Т.Д. Шевеленковой, П.П. Фесенко [6, С. 115]. Целью методики является определение уровня психологического благополучия и определения характера соотношения его компонентов.

2. «Шкала общей толерантности к неопределенности» Д. Макклейна в адаптации Е.Н. Осина. Целью данной методики является измерение склонности личности к жёсткой регламентации жизни и полной известности происходящего, либо открытости и неопределённости [3, С. 67].

3. Личностная шкала проявлений тревоги Дж. Тейлора в адаптации Т.А. Немчина. С помощью данного метода можно выявить уровень личной тревожности испытуемого, под которой мы понимаем устойчивую характеристику личности, дающая представление о предрасположенности человека к проявлению тревожности [2, С. 22].

4. Определение деструктивных установок в межличностных отношениях В.В. Бойко. Цель - выявление деструктивных установок в межличностных отношениях испытуемых [2, С. 24].

В результате исследования мы получили следующие выводы.

Перейдем к рассмотрению результатов уровня психологического благополучия: 7\% студентов-психологов второго и третьего курса имеют высокий уровень психологического благополучия, 66\% имеют средний уровень, низкий уровень представлен у $27 \%$ студентов.

Высокие значения психологического благополучия личности говорят нам о позитивном функционировании человека, которое выражается в субъективном ощущении удовлетворенностью жизнью, реализации собственного потенциала, высокой интегрированностью и опосредованный системой отношений личности (с другими, миром собой). 
Студенты с низким уровнем психологического благополучия не имеют опыт позитивных близких отношений со значимыми людьми. Отношения с другими выстраиваются по принципу контроля. А также они не могут полностью принять себя, им тяжелее расставлять приоритеты в жизни.

Рассмотрим результаты, полученные в ходе изучения тревожности у студентов-психологов.

Большинство (86\%) студентов-психологов имеют средний с тенденцией низкому уровень тревожности. Следовательно, студенты не склонны испытывать тревогу, беспокойство в различных ситуациях. Следует отметить, что оставшаяся часть студентов (14\%) имеют средний с тенденцией к высокому уровень тревожности. Такие испытуемые уже в большей степени проявляют тревогу, беспокойство в повседневной жизни.

При рассмотрении результатов уровня толерантности к неопределенности, мы видим, что среднегрупповое значение равно 14 баллам. Чем выше значения, тем выше уровень толерантности к неопределенности. Сниженные значения свидетельствуют о том, что студенты склонны испытывать дискомфорт в трудных, неоднозначных ситуациях, не выносят неизвестность. Чаще всего они стараются привнести в свою жизнь однозначность и ясность. Повышенные значения показывают нам, что испытуемые способны находить различные пути выхода из трудноразрешимых ситуаций, их не пугают сложности и неоднозначность.

В результате исследования можно сделать следующие выводы: чем выше значения по каждому показателю, тем выше степень проявления той или иной деструктивной установки в межличностных отношениях у студентовпсихологов. Значение завуалированной жестокости равно 7 баллам, и выражает степень негативности по поводу окружающих, которые испытуемые прячут и не проявляют открыто в контактах. Значение открытой жестокости по отношению к людям (12), указывает на снисходительные оценки в отношении окружающих людей, а также мнение об окружающих может изменяться в зависимости от ситуации. У студентов-психологов обоснованный негативизм в суждениях о людях имеет средние значения (2), чем выше показатель, тем выше объективные отрицательные выводы о некоторых типах людей. Брюзжание также находится в средних значениях (2). Данный показатель свидетельствует о наличии или отсутствии склонности делать необоснованные 
обобщения негативных фактов в области взаимоотношений с партнерами. Негативный личный опыт, значение этого показателя равно 11 баллам. Данный показатель указывает, в какой мере испытуемым повезло иметь ближайший круг знакомых и партнеров по совместной деятельности, и был ли у них негативный опыт взаимодействия с ними.

Таким образом, можно сделать вывод об уровне психологического благополучия студентов психологов второго и третьего курсов в процессе дистанционного обучения. В преобладающем большинстве студенты имею средние показатели по таким параметрам как: уровень тревожности, уровень толерантности к неопределенности, уровень психологического благополучия. Выраженность деструктивных установок также находятся на среднем уровне. Данные факты указываю на целесообразность психолого-педагогического сопровождения студентов-психологов с целью повышения психологического благополучия личности.

\section{БИБЛИОГРАФИЧЕСКИЙ СПИСОК}

1. Бессонова Ю. В. О структуре психологического благополучия // Психологическое благополучие личности в современном образовательном пространстве: сб. статей / сост. Ю. В Братчикова. - Екатеринбург: Урал. гос. пед. ун-т, 2013. - С. 30-36.

2. Карелин А. Большая энциклопедия психологических тестов. - М.: Эксмо, 2007. - С. 22-24.

3. Осин Е. Н. Факторная структура версии шкалы общей толерантности к неопределённости Д. МакЛейна. // Психологическая диагностика. - 2010. - № 2. - С. 65-86.

4. Фомина О. О. Благополучие личности: проблемы и подходы к исследованию в отечественной психологии // Интернет-журнал «Мир науки». 2016. - Том 4. - № 6. URL: http://mir-nauki.com/PDF/53PSMN616.pdf (дата обращения: 14.04.2021).

5. Шамионов Р. М. Субъективное благополучие личности как субъекта социального бытия // Известия Сарат. университета. - Серии: «Философия. Психология. Педагогика». - 2014. - Т. 14 - № 1. - С. 80-84. 
6. Шевеленкова Т. Д., Фесенко П. П. Психологическое благополучие личности (обзор основных концепций и методика исследования) // Психологическая диагностика. - 2005. - № 3. - С. 95-121.

7. Ryff C. D. Singer B. Human Health: New Directions for the Next Millennium // Psychological Inquiry. - 1998. - Vol. 9. - P. 69-85.

Усынина Т. П., Цветнова А. Д. Психологическое благополучие студентов и факторы, его определяющие // Вестник Совета молодых учёных и специалистов Челябинской области. - 2017. - Т. 2. - № 1. - С. 122-124. 